\title{
Pembinaan Akhlak Peserta Didik melalui Program Mentoring di SMP X Bandung
}

\author{
Siti Alimah*, Arif Hakim \\ Prodi Pendidikan Agama Islam, Fakultas Tarbiyah dan Keguruan, \\ Universitas Islam Bandung, Indonesia. \\ *siti.alimah2505@gmail.com, arifhakim.spsupi@gmail.com
}

\begin{abstract}
Education does not only produce intelligent humans, but humans who have noble character or good character, because noble character or good character is seen as more important in human life. SMP X Bandung was one of schools that has done the cultivation of Noble character on students through mentoring programs. The purpose of this research was to get the information about the planning of mentoring programs, identified the activity of mentoring programs, and explained the character (responsibility) of the students in following the mentoring program activities at SMP X Bandung. The method used in this research was interview, observation, and documentary study. Based on the research that has been done, it was concluded that: (1) The mentoring program planning that was defined into the Mentoring Curriculum of SMP X Bandung, which included: Basic Competences, Fundamental Materials, Achievement Indicators, Study Activities, Material Deepening, and Assessment. (2) Its implementation was material delivery, questions and answers, the Qur'an reading test/ Iqra. (3) The students' character: 1. Responsible for their duties as Muslims, that was reading the Qur'an/ Iqra right and proper. The students that had the ability to read the Qur'an/Iqra with the criteria: a. Excellent: 3,5\%, b. Good: 60\%, c. Satisfactory: 35,7\%. 2. Responsible for their duties as students, which was following the mentoring program activities. The students that followed the mentoring program activities by criteria: a. Very regular: $50 \%$, Regular: $21,4 \%$, c. Fairly regular: $17,8 \%$, dan d. Not regular: $10,7 \%$.
\end{abstract}

Keywords: Coaching, Character, Mentoring.

Abstrak. Pendidikan bukan hanya menghasilkan menusia yang cerdas, tetapi manusia yang berakhlak mulia atau berkarakter baik, sebab akhlak mulia atau karakter yang baik, dipandang lebih penting dalam kehidupan manusia. SMP X Bandung merupakan salah satu sekolah yang telah melakukan pembinaan akhlak kepada peserta didik, melalui program mentoring. Tujuan penelitian ini adalah untuk mendapatkan informasi mengenai perencanaan program mentoring, mengidentifikasi kegiatan program mentoring, dan menjelaskan akhlak (tanggung jawab) peserta didik dalam mengikuti kegiatan program mentoring di SMP X Bandung. Metode yang digunakan dalam penelitian ini adalah deskriptif analitik dengan pendekatan kualitatif. Teknik pengumpulan data yang digunakan adalah wawancara, observasi, dan studi dokumentasi. Berdasarkan penelitian yang telah dilakukan, dapat disimpulkan bahwa: (1) Perencanaan program mentoring yang dirumuskan ke dalam Kurikulum Mentoring SMP X Bandung, di dalamnya terdapat: Kompetensi Dasar, Materi Pokok, Indikator Pencapaian, Kegiatan Pembelajaran, Pendalaman Materi, dan Penilaian. (2) Implementasinya adalah Penyampaian materi, Tanya jawab, Tes bacaan Al-Qur'an/Iqra. (3) Akhlak peserta didik: 1. Bertanggung jawab terhadap kewajibannya sebagai seorang muslim yakni membaca Al-Qur'an/Iqra dengan baik dan benar. Peserta didik yang memiliki kemampuan membaca Al-Qur'an/Iqra dengan kriteria : a. Sangat Baik: 3,5\%, b. Baik: 60,7\%, c. Cukup baik: 35,7 \%. 2. Bertanggung jawab terhadap tugasnya sebagai peserta didik yakni mengikuti kegiatan program mentoring. Peserta didik yang mengikuti kegiatan program mentoring dengan kriteria: a. Sangat rutin: $50 \%$, b. Rutin: $21,4 \%$, c. Cukup rutin: 17,8 \%, dan d. Tidak rutin: 10,7\%.

Kata Kunci: Pembinaan, Akhlak, Mentoring 


\section{A. Pendahuluan}

Komisioner Komisi Perlindungan Anak Indonesia (KPAI) Bidang Hak Sipil dan Partisipasi Anak, Jasra Putra mengatakan, kejadian mengenai siswa yang jarinya harus diamputasi, hingga siswa yang ditendang sampai meninggal, menjadi gambaran ekstrem dan fatal dari intimidasi bullying fisik dan psikis yang dilakukan pelajar kepada teman-temannya pada Februari 2020. Data pengaduan anak kepada KPAI bagai fenomena gunung es. Artinya, yang tampak di permukaan hanya sejumlah kecil, sedangkan yang tidak tampak karena tidak terlaporkan disyinyalir kasusnya jauh lebih banyak. KPAI mencatat dalam kurun waktu 9 tahun, dari 2011 sampai 2019, terdapat 37.381 pengaduan kekerasan terhadap anak. Untuk Bullying (fisik dan psikis), baik di dunia pendidikan maupun sosial media, angkanya mencapai 2.473 pengaduan, laporan dan trennya terus meningkat. Sama seperti pernyataan Presiden pada ratas (9/1/2020) melalui Data SIMFONI PPA. Bahkan, Januari sampai Februari, kita terus setiap hari membaca berita dan menonton fenomena kekerasan anak. Tentunya ini sangat disadari dan menjadi keprihatinan bersama (https://jabar.tribunnews.com).

Data-data di atas menjelaskan tentang kemerosotan akhlak atau karakter yang terjadi di kalangan kaum terpelajar. Seperti contoh kasus di atas bahwa, kebiasaan mengejek dan menghina (bullying fisik dan psikis) yang dilakukan oleh siswa kepada teman-temannya sudah menjadi hal yang umum dan lazim untuk ditonton, bahkan telah merajalela dimana-mana. Ironis jika sebagai kaum terdidik membiarkan kemerosotan akhlak ini terus berlanjut.

Dalam agama Islam, pendidikan karakter memiliki kemiripan dengan pendidikan akhlak. Istilah akhlak bahkan sudah masuk ke dalam Kamus Besar Bahasa Indonesia (KBBI) yaitu akhlak, yang artinya budi pekerti dan atau kelakukan. Pendidikan karakter atau akhlak memerlukan peneladanan dan pembiasaan, karena karakter tidak terbentuk secara instan melainkan harus dilatih secara serius, terus menerus dan proporsional, agar mencapai bentuk yang optimal. Dalam konteks pendidikan di Indonesia, pemerintah RI melalui rumusan Kemendikbud (2010) menetapkan 18 nilai karakter yang harus dikembangkan pada peserta didik di setiap satuan jenis dan jenjang pendidikan, di antaranya yaitu tanggung jawab serta disiplin. Dalam hal ini yang dimaksud dengan tanggung jawab ialah seorang peserta didik harus mampu bertanggung jawab dengan penuh terhadap kewajibannya sebagai seorang muslim dan terhadap tugasnya sebagai seorang peserta didik. Disiplin sendiri berarti harus sesuai dan tepat dengan ketentuan yang berlaku.

Salah satu sekolah yang telah melakukan pembinaan akhlak kepada peserta didik yaitu SMP X Bandung. Pada hari Selasa tanggal 10 Maret 2020, peneliti melakukan wawancara dengan bagian kesiswaan SMP X Bandung, beliau mengatakan bahwa "SMP X Bandung telah merancang beberapa program unggulan, salah satu di antaranya yaitu program mentoring. Sebagai upaya yang dilakukan dalam membentuk kepribadian peserta didik agar berakhlak mulia, unggul, dan berprestasi”.

Mentoring merupakan salah satu sarana Tarbiyah Islamiyah (pembinaan/ pendidikan Islami) yang didalamnya terdapat peroses pembelajaran dalam rangka pembentukan kepribadian muslim dan penanaman nilai-nilai Agama (Ruswandi, 2012: 1). Melalui program mentoring tersebut, peserta didik dibina untuk meneladani akhlak Rasul Shallallahu'alayhi waSallam, baik dalam perkataan maupun perbuatan, dan menerapkannya dalam kehidupan sehari-hari. Dengan demikian, diharapkan peserta didik terhindar dari permasalah kerusakan akhlak yang terjadi di kalangan pelajar.

Al-Qur'an menetapkan bahwa akhlak itu tidak terlepas dari aqidah dan syari'ah, ketiganya merupakan satu kesatuan yang tidak dapat dipisahkan. Hal ini dapat dilihat dalam Q.S. al-Baqarah/2: 177.

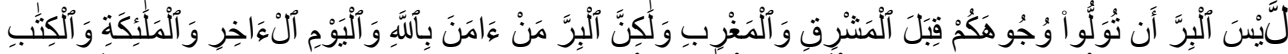

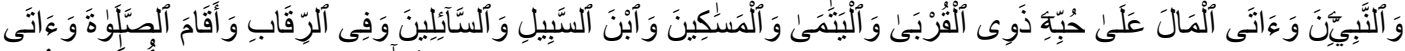

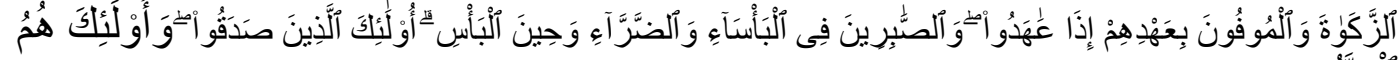

$$
\begin{aligned}
& \text { أَلْنَتَُّْونَ }
\end{aligned}
$$

Dalam kegiatan program mentoring di SMP X Bandung, terdapat hal-hal yang dilakukan secara rutin, di antaranya yakni: melakukan sholat fardhu, sholat dhuha, pendalaman 
PAI (Aqidah, Ibadah, dan Akhlak), BTAQ (Baca Tulis al-Quran), Doa dan Dzikir bersama, Tadarusan, hafalan Juz 'Amma, hafalan Asmaul Husna, muraja'ah hafalan, membaca Shirah Nabawiyah, membaca Hadits, membaca kisah inspiratif, serta belajar praktik ibadah seperti tatacara sholat, wudhu, dan mengurus jenazah.

Dalam pelaksanaan program mentoring di SMP X Bandung, peserta didik dibina dan dilatih untuk bertanggung jawab dan disiplin terhadap kewajibannya serta terhadap tugas yang diberikan oleh guru, yang kemudian akan dinilai sebagai penilaian akademik. Bagi peserta didik yang tidak bertanggung jawab dan disiplin terhadap kewajibannya serta terhadap tugas yang diberikan oleh guru, maka akan mendapatkan sanksi atau hukuman (yang mengedukasi). Dengan begitu, diharapkan karakter tanggung jawab dan disiplin bisa melekat pada diri peserta didik, sebagai cerminan dari akhlak mulia.

Untuk meminimalisir dan memecahkan masalah kemerosotan akhlak yang tejadi di kalangan para pelajar, maka perlu adanya pembinaan akhlak kepada peserta didik. Melalui program mentoring, peserta didik dibina untuk meneladani akhlak Rasul Shallallahu 'alayhi waSallam dalam kehidupan sehari-hari, salah satunya yaitu bertanggung jawab terhadap kewajiban dan tugasnya sebagai seorang muslim sekaligus sebagai peserta didik di SMP X Bandung.

Berdasarkan latar belakang yang telah diuraikan, maka tujuan yang hendak dicapai dalam penelitian ini adalah sebagai berikut:

1. Memperoleh data atau informasi yang berkaitan dengan perencanaan kegiatan program mentoring dalam membina akhlak peserta didik di SMP X Bandung, berupa laporan tertulis.

2. Mengidentifikasi kegiatan program mentoring dalam membina akhlak peserta didik di SMP X Bandung.

3. Menjelaskan akhlak (tanggung jawab) peserta didik, dalam mengikuti kegiatan program mentoring di SMP X Bandung.

\section{B. Metodologi Penelitian}

\section{Pendekatan dan Metode}

Pendekatan penelitian yang penulis gunakan adalah pendekatan kualitatif, sedangkan metodenya adalah deskripif analitik. Penelitian ini dilakukan untuk mendeskripsikan atau menggambarkan suatu kondisi nyata apa adanya tentang perencanaan program mentoring, pelaksanaan program mentoring, dan penilaian akhlak (tanggung jawab) peserta didik dalam mengikuti kegiatan program mentoring di SMP X Bandung secara sistematis kemudian peneliti menganalisis data dan fakta sesuai dengan teori yang relevan.

\section{Lokasi Penelitian}

Penelitian ini dilakukan di SMP X Bandung yang terletak di Jl. Panatayuda No. 2 Bandung Jawa Barat. Peneliti tertarik melakukan penelitian di SMP X Bandung ini, dikarenakan SMP X Bandung adalah salah satu sekolah swasta Islam yang telah melakukan pembinaan akhlak kepada peserta didik, sehingga SMP X Bandung diharapkan dapat memberikan inspirasi bagi sekolah lain di sekitarnya, dalam hal ini khususnya terkait dengan pembinaan akhlak (tanggung jawab) peserta didik melalui kegiatan program mentoring.

\section{Teknik Pengumpulan Data}

1. Wawancara

Dalam penelitian ini, peneliti melakukan wawancara dengan bagian Kesiswaan, Wakil Kepala Sekolah Kurikulum, dan Koordinator sekaligus Pembina mentoring di SMP X Bandung. Peneliti melakukan wawancara mengenai perencanaan kegiatan program mentoring, pelaksanaan kegiatan program mentoring, serta penilaian akhlak (tanggung jawab) peserta didik dalam mengikuti kegiatan program mentoring di SMP X Bandung

2. Observasi

Dalam penelitian ini, peneliti hanya sebatas mengamati pelaksanaan program mentoring di SMP X Bandung tanpa terlibat dalam pelaksanaan kegiatan tersebut. 
3. Dokumentasi

Dalam penelitian ini, peneliti mengumpulkan data-data penunjang penelitian di antaranya yaitu perencanaan program mentoring dalam bentuk dokumen tertulis, dokumentasi kegiatan dalam bentuk foto, dan lembar penilaian akhlak (tanggung jawab) peserta didik dalam bentuk lembar penilaian.

\section{Teknik Analisis Data}

1. Pengumpulan Data

Dalam penelitian ini, data yang dikumpulkan berupa hasil wawancara dengan informan mengenai perencanaan kegiatan program mentoring, proses pelaksanaan kegiatan program mentoring, serta penilaian akhlak (tanggung jawab) peserta didik dalam mengikuti kegiatan program mentoring, yang diselenggarakan di SMP X Bandung. Adapun data pendukung penelitian yang diperoleh ialah berupa dokumen tertulis mengenai perencanaan kegiatan program mentoring, foto-foto kegiatan pelaksanaan program mentoring, serta lembar penilaian akhlak (tanggung jawab) peserta didik dalam mengikuti kegiatan program mentoring di SMP X Bandung.

2. Reduksi Data

Dalam penelitian ini, penulis mereduksi data dari hasil wawancara, observasi, dan studi dokumentasi yaitu menfokuskan data mengenai perencanaan kegiatan program mentoring, pelaksanaan kegiataan program mentoring, penilaian akhlak (tanggung jawab) peserta didik selama mengikuti kegiatan program mentoring di SMP X Bandung.

3. Penyajian Data

Dalam penelitian ini, data hasil penelitian yang telah diperoleh melalui wawancara, observasi, dan studi dokumentasi, mengenai perencanaan kegiatan program mentoring, pelaksanaan kegiatan program mentoring, serta mengenai akhlak (tanggung jawab) peserta didik dalam mengikuti kegiatan program mentoring di SMP X Bandung, akan disajikan dalam bentuk deskripsi, tabel dan sejenisnya. Penyajian data dilakukan agar lebih memudahkan bagi peneliti untuk dapat melihat gambaran secara keseluruhan terkait penelitian yang telah dilakukan di SMP X Bandung.

4. Penarikan Kesimpulan/ Verifikasi

Dalam penelitian ini, penulis akan memberikan kesimpulan mengenai perencanaan kegiatan program mentoring, pelaksanaan kegiatan program mentoring, serta akhlak (tanggung jawab) peserta didik dalam mengikuti kegiatan program mentoring yang diselenggarakan oleh SMP X Bandung.

\section{Hasil Penelitian dan Pembahasan}

Data hasil penelitian lapangan mengenai Pembinaan Akhlak Peserta didik melalui Program Mentoring di SMP X Bandung, akan dianalisis menggunakan teori-teori yang berkaitan, dengan pendekatan deskriptif kualitatif dan teknik pengumpulan data yaitu wawancara, observasi dan studi dokumentasi. Dari beberapa rumusan masalah yang telah dikemukakan sebelumnya, peneliti telah memperoleh berbagai informasi mengenai perencanaan program mentoring, implementasi program mentoring, dan akhlak (tanggung jawab) peserta didik dalam mengikuti kegiatan program mentoring, di SMP X Bandung. Berdasarkan hal tersebut, maka dalam Sub Bab ini, peneliti akan mendeskripsikan pembahasan dan diskusi sebagai berikut:

\section{Perencanaan Program Mentoring}

Sebagaimana yang telah diketahui bersama bahwa, setiap program tentunya memerlukan suatu perencanaan, agar tujuan program dapat tercapai, dan kegiatan program dapat berjalan dengan lancar sesuai dengan yang telah direncanakan. Begitu pula halnya dengan SMP X Bandung, ketika hendak merealisasikan program mentoring, SMP $X$ Bandung telah merancang perencanaan kegiatan program mentoring, yang dirumuskan ke dalam Kurikulum Mentoring SMP X Bandung, sebagai pedoman dalam pelaksanaan kegiatan program mentoring.

Berdasarkan data dalam bentuk dokumen tertulis yang telah peneliti peroleh dari Koordinator program mentoring SMP X Bandung, diketahui bahwa SMP X Bandung telah 
menyusun perencanaan kegiatan program mentoring, yang dirumuskan ke dalam Kurikulum Mentoring SMP X Bandung, untuk digunakan sebagai pedoman dalam perlaksanaan kegiatan program mentoring, berikut adalah uraiannya: Di dalam kurikulum mentoring SMP X Bandung, tercantum kegiatan yang akan dilakukan selama 6 bulan pertama (Setiap minggu ke-1) di antaranya yakni, mengenai kompetensi dasar yang harus dimiliki oleh peserta didik ialah meningkatkan kajian pemahaman dan pengamalan keislaman dalam kehidupan sehari-hari. Adapun materi pokok yang akan diberikan yaitu Pertama, pelatihan ibadah shalat fardhu dan berjama'ah sesuai dengan Sunnah Nabi (Fiqih). Kedua, pembahasan pribadi muslim yang berakhlak karimah (Akhlak). Ketiga, pelatihan menulis Al-Qur'an (BTAQ). Keempat, pelatihan tahsin Al-Qur'an dan wisuda Tahfidz Juz 30 (Hafidz). Indikator pencapaiannya adalah peserta didik mampu melaksanakan ibadah shalat sesuai dengan Sunnah Nabi, peserta didik memiliki akhlak yang baik atau akhlak PGII (Rabbani), peserta didik mampu menulis Al-Qur'an sesuai dengan kaidah yang baik dan benar, serta peserta didik mampu membaca Al-Qur'an dengan tartil. Lalu, pada kegiatan pembelajarannya yaitu diawali dengan kegiatan Mengamati, dalam kegiatan ini peserta didik memperhatikan penjelasan dari pemateri. Setelah pemateri selesai menjelaskan materi, peserta didik diberi kesempatan untuk bertanya kepada pemateri mengenai materi yang disampaikan. Setelah pemateri selesai menjawab pertanyaan yang diajukan oleh peserta didik, pemateri melanjutkan kegiatan berikutnya yaitu peserta didik diarahkan untuk mencari pendalaman materi dengan mencari sumber-sumber lain selain sumber dari slide yang disampaikan oleh pemateri, hal tersebut dilakukan dalam rangka eksplorasi dan asosiasi. Adapun kegiatan pembelajaran yang terakhir yaitu komunikasi, dalam kegiatan ini peserta didik diarahkan untuk berdiskusi dengan temannya, membahas dan mendiskusikan hasil dari materi. Tahap selanjutnya ialah pendalaman materi, pada tahap ini setiap pementor akan melakukan pengetesan bacaan shalat dan praktek shalat kepada peserta didik. Selain demikian, peserta didik juga dibimbing agar mengamalkan materi yang telah disampaikan dalam kehidupan sehari-hari (dibuatkan video) dan mengadakan kantin kejujuran. Selanjutnya, peserta didik diarahkan untuk membuat dan memahami macam-macam bentuk huruf Hijaiyah atau huruf Arab. Kemudian memberikan informasi hafalan kepada pementor setiap minggunya. Perihal penilaiannya, pementor menggunakan jenis tagihan sebagai berikut: tes praktek, video, tes tulis, form hafalan siswa (buku monitoring). Sedangkan bentuk instrumennya ialah lembar penilaian tes tulis, praktek, video, dan buku monitoing.

Adapun kegiatan yang akan dilakukan selama 6 bulan pertama (Minggu ke-2, 3, dan 4) sebagai berikut: Kompetensi Dasar yang harus dikuasai oleh peserta didik ialah mampu membaca Al-Qur'an dengan baik dan benar, dan mengaplikasikan dalam keseharian. Adapun materi pokok yang akan diberikan yaitu tentang "Al-Qur'an sebagai pedoman hidup manusia". Indikator pencapaiannya adalah seluruh peserta didik diharapkan bebas dari buta huruf AlQur'an. Lalu, pada kegiatan pembelajarannya yaitu diawali dengan kegiatan mengamati, dalam kegiatan ini peserta didik diminta untuk memperhatikan penjelasan materi yang disampaikan oleh pementor. Setelah pementor selesai menjelaskan materi, peserta didik diberi kesempatan untuk bertanya kepada pementor mengenai kekurangan dari bacaannya masing-masing. Setelah pementor selesai menjawab pertanyaan yang diajukan oleh peserta didik, pementor melanjutkan kegiatan berikutnya yaitu peserta didik diarahkan untuk mencari kesalahan dan kekurangan pada bacaan teman-temannya, hal tersebut dilakukan dalam rangka eksplorasi dan asosiasi. Adapun kegiatan pembelajaran yang terakhir yaitu komunikasi, dalam kegiatan ini peserta didik diarahkan untuk mencoba mengikuti dan memperbaiki bacaannya sesuai dengan bacaan pementor masing-masing. Tahap selanjutnya ialah pendalaman materi, pada tahap ini pementor akan melakukan pengetesan dan penjelasan kemampuan bacaan Al-Qur'an peserta didik, kemudian pementor melakukan pengenalan dan pemaparan huruf Hijaiyah serta tanda baca (Fathah, Kasrah, dan Dhammah), setelah itu, barulah dilakukan pengecekan kemampuan bacaan peserta didik, untuk diklasifikasikan sesuai dengan kemampuannya masing-masing (Iqra $1 \mathrm{~s} / \mathrm{d}$ Iqra 6). Perihal penilaiannya, pementor menggunakan jenis tagihan "tes bacaan", sedangkan bentuk instrumennya ialah lembar penilaian tes bacaan.

Adapun kegiatan yang akan dilakukan selama 6 bulan kedua (setiap minggu ke-1) di antaranya yakni, mengenai kompetensi dasar yang harus dimiliki oleh peserta didik ialah 
meningkatkan kajian pemahaman dan pengamalan keislaman dalam kehidupan sehari-hari. Adapun materi pokok yang akan diberikan yaitu Pertama, pelatihan penetapan makanan dan minuman yang halal dan haram berdasarkan Al-Qur'an dan Hadits (Fiqih). Kedua, pelatihan pengurusan jenazah (Fiqih). Ketiga, pelatihan maqamat Al-Qur'an dan wisuda Tahfidz atau Tasmi' Juz 30 (Hafidz). Indikator pencapaiannya adalah peserta didik mempunyai pemahaman dalam penetapan makanan dan minuman yang baik dan tidak baik untuk dikonsumsi, peserta didik mempunyai kemampuan dalam pengurusan jenazah sesuai dengan kaidah fiqih, peserta didik mempunyai kemampuan membaca dan menghafal Al-Qur'an dengan tartil. Lalu, pada kegiatan pembelajarannya yaitu diawali dengan kegiatan mengamati, dalam kegiatan ini peserta didik memperhatikan penjelasan dari pemateri. Setelah pemateri selesai menjelaskan materi, peserta didik diberi kesempatan untuk bertanya kepada pemateri mengenai materi yang disampaikan. Setelah pemateri selesai menjawab pertanyaan yang diajukan oleh peserta didik, pemateri melanjutkan kegiatan berikutnya yaitu peserta didik diarahkan untuk mencari pendalaman materi dengan mencari sumber-sumber lain selain sumber dari slide yang disampaikan oleh pemateri, hal tersebut dilakukan dalam rangka eksplorasi dan asosiasi. Adapun kegiatan pembelajaran yang terakhir yaitu komunikasi, dalam kegiatan ini peserta didik diarahkan untuk berdiskusi dengan temannya, membahas dan mendiskusikan hasil dari materi. Tahap selanjutnya ialah pendalaman materi, pada tahap ini setiap peserta didik diarahkan untuk melakukan pengklasifikasian makanan dan minuman yang halal dan haram. Selain demikian, peserta didik juga dibimbing agar mengamalkan materi yang telah disampaikan dalam kehidupan sehari-hari (dibuatkan video). Selanjutnya, peserta didik diarahkan untuk memberikan informasi hafalan kepada pementor setiap minggunya. Perihal penilaiannya, pementor menggunakan jenis tagihan sebagai berikut: tes praktek shalat, video, tes tulis, form hafalan siswa (buku monitoring). Sedangkan bentuk instrumennya ialah lembar penilaian tes tulis, praktek, video, dan buku monitoing.

Adapun kegiatan yang akan dilakukan selama 6 bulan kedua (Minggu ke 2, 3, dan 4), perencanaannya sama persis seperti kegiatan selama 6 bulan pertama (Minggu ke 2, 3, dan 4). Perencanaan inilah yang diterapkan oleh SMP X Bandung dalam merealisasikan program mentoring pada masa pandemi Covid 19 tahun ajaran 2021, di antaranya yakni, mengenai Kompetensi Dasar yang harus dikuasai oleh peserta didik ialah mampu membaca Al-Qur'an dengan baik dan benar, dan mengaplikasikan dalam keseharian. Adapun materi pokok yang akan diberikan yaitu tentang "Al-Qur'an sebagai pedoman hidup manusia". Indikator pencapaiannya adalah seluruh peserta didik diharapkan bebas dari buta huruf Al-Qur'an. Lalu, pada kegiatan pembelajarannya yaitu diawali dengan kegiatan mengamati, dalam kegiatan ini peserta didik diminta untuk memperhatikan penjelasan materi yang disampaikan oleh pementor. Setelah pementor selesai menjelaskan materi, peserta didik diberi kesempatan untuk bertanya kepada pementor mengenai kekurangan dari bacaannya masing-masing. Setelah pementor selesai menjawab pertanyaan yang diajukan oleh peserta didik, pementor melanjutkan kegiatan berikutnya yaitu peserta didik diarahkan untuk mencari kesalahan dan kekurangan pada bacaan teman-temannya, hal tersebut dilakukan dalam rangka eksplorasi dan asosiasi. Adapun kegiatan pembelajaran yang terakhir yaitu komunikasi, dalam kegiatan ini peserta didik diarahkan untuk mencoba mengikuti dan memperbaiki bacaannya sesuai dengan bacaan pementor masingmasing. Tahap selanjutnya ialah pendalaman materi, pada tahap ini pementor akan melakukan pengetesan dan penjelasan kemampuan bacaan Al-Qur'an peserta didik, kemudian pementor melakukan pengenalan dan pemaparan huruf Hijaiyah serta tanda baca (Fathah, Kasrah, dan Dhammah), setelah itu, barulah dilakukan pengecekan kemampuan bacaan peserta didik, untuk diklasifikasikan sesuai dengan kemampuannya masing-masing (Iqra 1 s/d Iqra 6). Perihal penilaiannya, pementor akan mengetes kembali bacaan peserta didik pada setiap pertemuan, penilaian tersebut dicatat ke dalam lembar penilaian tes bacaan (Data Peserta Mentoring 2021) yang telah disediakan bagi setiap pementor.

\section{Pelaksanaan Program Mentoring}

Pelaksanaan kegiatan program mentoring, tidak bisa terlepas dari yang namanya seorang pembina, sebab pembina merupakan orang yang memberikan ilmu pengetahuan dan bimbingan 
kepada peserta binaanya. Hal ini sejalan dengan pendapat Ahmad Zaenuri yakni, Halaqah Tarbawiyah atau biasa disebut juga dengan mentoring, merupakan kegiatan kajian islam dengan jumlah anggota terbatas (biasanya tidak lebih dari 12 orang) yang dipandu oleh seorang pementor (Pembina Mentoring). Fungsi dari kegiatan ini adalah sebagai sarana untuk menghasilkan pribadi yang berkualitas secara Dalam pelaksanaan kegiatan program mentoring pada masa Pandemi Covid 19, khususnya di tahun 2021, SMP X Bandung memfasilitasi dan membimbing para peserta didik dalam mempelajari cara membaca Al-Qur'an dengan baik dan benar, yang diawali dengan mengenalkan huruf-huruf hijaiyah terlebih dahulu. Hal ini sejalan dengan pendapat Suku Radja yakni, Membaca al-Qur'an adalah sebuah kebutuhan wajib dan pokok bagi setiap muslim. Sebab, dengan membaca Al-Qur'an, keimanan kita semakin meningkat, menjadikan kita bertambah dekat dengan Allah SuhanahuwaTa'ala, serta merupakan cara termudah untuk semakin paham dengan ayat-ayat Allah SubhanahuwaTa'ala. Sementara itu, tidak sedikit umat muslim yang belum mampu membaca Al-Quran yang tertulis dengan huruf-huruf arab. Oleh karena itu, sangat penting bagi mereka untuk mengenal huruf hijaiyah terlebih dahulu (Radja, 2018:9).

\section{Akhlak (tanggung jawab) Peserta didik}

SMP X Bandung telah melakukan pembinaan Akhlak kepada peserta didik melalui kegiatan program mentoring, yang diawali dengan memberikan materi tentang "Al-Qur'an sebagai pedoman hidup manusia", hal ini mengacu pada Misi sekolah yaitu Menjadikan nilai-nilai Islam sebagai ruh dan dasar bagi pengelolaan pendidikan (Islam Disiplin Ilmu/ IDI). Dengan begitu, diharapkan peserta didik dapat memahami nilai-nilai tersebut, serta mampu mengaplikasikannya dalam keseharian.

Seseorang yang menjadikan Al-Qur'an sebagai pedoman dalam hidupnya, tentu ia akan mengimplentasikan nilai-nilai ajaran Islam tersebut dalam kehidupannya sehari-hari, termasuk menjalankan kewajiban dan tanggung jawabnya, baik terhadap Sang Pencipta, negara, lingkungan, masyarakat, maupun atas dirinya sendiri. Sebab, ia telah mengimani dan memahami bahwa kelak di akhirat ia akan dimintai pertanggungjawaban oleh Allah, atas perbuatannya selama hidup di dunia. Sebagaimana firman-Nya:

"Tiap-tiap diri bertanggung jawab atas apa yang telah diperbuatnya" (Q.S. alMuddassir/74: 38)

Dalam penelitian ini, akhlak peserta didik dapat dilihat dari dua hal yaitu penilaian perkembangan kemampuan bacaan Iqra peserta didik, sebagai cerminan bahwa ia telah bertanggung jawab terhadap kewajibannya sebagai seorang muslim (salah satunya yakni membaca Al-Qur'an dengan baik dan benar). Serta, akhlak peserta didik dapat juga dilihat dari kehadiran peserta didik dalam mengikuti kegiatan program mentoring, sebagai cerminan bahwa ia telah bertanggung jawab terhadap kewajiban dan tugasnya sebagai peserta didik di SMP $X$ Bandung yakni mengikuti kegiatan program mentoring. Hal ini sejalan dengan pendapat Nata A yakni Untuk menentukan kesuksesan dalam sebuah program, maka harus ada proses menilai. Menilai adalah mengambil suatu keputusan terhadap sesuatu dengan ukuran baik dan buruk, dan sifatnya dalah kualitatif, selanjutnya melakukan evaluasi (Nata A, 2005: 185).

Berdasarkan hasil studi dokumentasi, mengenai Data Perkembangan Bacaan Iqra Peserta Mentoring 2021 yaitu, peserta didik yang memiliki kemampuan bacaan dengan kriteria Sangat Baik yakni 3,5\% terdiri dari 1 orang; peserta didik yang memiliki kemampuan bacaan Iqra dengan kriteria Baik yakni 60,7\% atau sebanyak 17 orang yang terdiri dari 12 orang kelas VII dan 5 orang peserta didik kelas VIII; serta peserta didik yang memiliki kemampuan bacaan Iqra dengan kriteria cukup baik yakni 35,7\% atau sebanyak 10 orang.

Selanjutnya, mengenai Data Kehadiran Peserta dalam mengikuti kegiatan program mentoring, sebagai berikut yakni, peserta didik yang mengikuti kegiatan mentoring dengan sangat rutin yaitu $50 \%$ atau sebanyak 14 orang yang terdiri dari 13 orang peserta didik kelas VII dan 1 peserta orang didik kelas VIII, sedangkan peserta didik yang mengikuti kegiatan mentoring dengan rutin yaitu 21,4\% atau sebanyak 6 orang yang terdiri dari 5 orang peserta didik kelas VII dan 1 orang peserta didik kelas VIII, selanjutnya peserta didik yang mengikuti 
kegiatan program mentoring dengan cukup rutin yaitu $17,8 \%$ atau sebanyak 5 orang yang terdiri dari 3 orang peserta didik kelas VII dan 2 orang peserta didik kelas VIII, sedangkan peserta didik yang mengikuti kegiatan mentoring dengan tidak rutin yaitu $10,7 \%$ atau sebanyak tiga orang yang terdiri dari 2 orang peserta didik kelas VII dan 1 orang peserta didik kelas VIII.

Sebagaimana yang telah disampaikan oleh Koordinator Mentoring SMP X Bandung, melalui wawancara beliau menyampaikan bahwa, pada prinsipnya pembinaaan akhlak (tanggung jawab) peserta didik melalui program mentoring adalah salah satu upaya yang dilakukan SMP X Bandung, dalam membentuk kepribadian peserta didik, agar berakhlak mulia, unggul, dan berprestasi. Hal ini sejalan dengan pendapat Yamin, Santo, dan Utaya, yakni Peserta didik tidak hanya bertanggung jawab atas tugas pembelajaran semata. Namun harus ia pahami, bagaimana prilaku yang peserta didik lakukan harus selaras dengan norma-norma, baik bersifat vertical dan horizontal dalam kultur masyarakat setempat. Tanggung jawab ini kemudian menghindarkan peserta didik dari berbagai praktik kecurangannya ketika menjalani pembelajaran, seperti datang terlambat, bolos, perkelahian, bullying, apatis, nyontek (Yasmin, Santoso, \& Utaya, 2016: 693) yang akan menjerumuskannya dalam prilaku menyimpang.

\section{Kesimpulan}

Berdasarkan hasil penelitian dan pembahasan mengenai Pembinaan akhlak Peserta didik melalui Program Mentoring di SMP X Bandung, di antaranya meliputi perencanaan program mentoring, pelaksanaan program mentoring, dan akhlak (tanggung jawab) peserta didik dalam mengikuti kegiatan program mentoring, yang telah diuraikan, maka dalam Bab ini penulis akan memaparkan kesimpulan sebagai berikut:

- Perencanaan

SMP X Bandung telah merancang perencanaan kegiatan program mentoring, yang dirumuskan ke dalam Kurikulum Mentoring SMP X Bandung. Namun, pada saat pandemi covid 19, SMP X Bandung memutuskan hanya berfokus pada pembinaan baca Al-Qur'an/Iqra saja, khususnya bagi peserta didik yang masih terbata-bata dalam membaca Al-Qur'an. Adapun kesimpulan mengenai perencanaan program mentoring yang digunakan selama masa pandemi Covid 19 ialah, sebagai berikut:

1. Kompetensi Dasar: Mampu membaca Al-Qur'ann dengan baik dan benar, dan mengaplikasikan dalam keseharian;

2. Materi Pokok: Al-Qur'an sebagai pedoman hidup manusia;

3. Indikator Pencapaian: Seluruh peserta didik diharapkan bebas dari buta huruf Al-Qur'an;

4. Kegiatan Pembelajaran:

a. Mengamati: Peserta didik memperhatikan penjelasan materi dari pementor;

b. Menanya: Peserta didik melalui motivasi dari pementor, peserta didik bertanya mengenai kekurangan dari bacaanya masing-masing;

c. Eksplorasi dan Assosiasi: Peserta didik mencari kesalahan dan kekurangan dari bacaan teman-temannya;

d. Komunikasi: Peserta didik mencoba mengikuti dan memperbaiki bacaannya, sesuai dengan bacaan dari pementor masing-masing.

5. Pendalaman Materi:

a. Pengetesan dan penjelasan kemampuan bacaan Al-Qur'an;

b. Pengenalan dan pemaparan huruf Hijaiyah serta tanda baca (Fathah, Kasrah, dan Dhammah);

c. Pengecekan kemampuan bacaan siswa sesuai dengan kemampuannya masing-masing (Iqra 1 s.d Iqra 6).

6. Penilaian:

a. Jenis Tagihan: Tes bacaan;

b. Bentuk Instrumen: Lembar penilaian tes bacaan.

- Pelaksanaan

Palaksanaan kegiatan program mentoring selama masa Pandemi Covid 19 khususnya di tahun 2021, yakni dilaksanakan secara luring terbatas di sekolah dengan tetap mematuhi 
protokol kesehatan. Namun, kadang kala pada kondisi tertentu pelaksanaan kegiatan program mentoring dilakukan juga secara daring, menggunakan platform Google Meet. Adapun hal-hal yang dilakukan dalam pelaksanaan kegiatan program mentoring ialah Pada pertemuan hari pertama, pementor memberikan materi secara singkat tentang "AlQur'an sebagai pedoman hidup manusia" yang di dalamnya terdapat penjelasan tentang wajibnya seorang muslim membaca Al-Qur'an dengan baik dan benar, peserta didik memperhatikan penjelasan materi yang disampaikan oleh pementor, kemudian peserta didik melakukan tanya jawab mengenai kekurangan dari bacaanya masing-masing, selanjutnya peserta didik diarahkan untuk mencari kesalahan dan kekurangan dari bacaan teman-temannya, kemudian peserta didik mencoba mengikuti dan memperbaiki bacaannya, sesuai dengan bacaan dari pementor masing-masing. Tahap selanjutnya ialah pendalaman materi, pada tahap ini pementor akan melakukan pengetesan dan penjelasan kemampuan bacaan Al-Qur' an peserta didik, kemudian pementor melakukan pengenalan dan pemaparan huruf Hijaiyah serta tanda baca (Fathah, Kasrah, dan Dhammah), setelah itu, barulah dilakukan pengecekan kemampuan bacaan peserta didik, untuk diklasifikasikan sesuai dengan kemampuannya masing-masing (Iqra 1 s/d Iqra 6). Kemudian, pementor akan mengetes kembali bacaan peserta didik pada setiap pertemuan, untuk dinilai dan dicatat ke dalam lembar penilaian (Data Peserta Mentoring 2021).

\section{- Akhlak}

Akhlak peserta didik yang dimaksud dalam penelitian ini yaitu peserta didik mampu bertanggung jawab terhadap kewajibannya sebagai seorang muslim (salah satunya yakni mampu membaca Al-Qur'an dengan baik dan benar), serta bertanggung jawab terhadap tugasnya sebagai seorang peserta didik di SMP X Bandung (salah satunya yakni mengikuti kegiatan program mentoring).

Berdasarkan hasil studi dokumentasi, mengenai Data Perkembangan Bacaan Iqra Peserta Mentoring 2021 yaitu, peserta didik yang memiliki kemampuan bacaan dengan kriteria Sangat Baik yakni 3,5 \% terdiri dari 1 orang; peserta didik yang memiliki kemampuan bacaan Iqra dengan kriteria Baik yakni $60,7 \%$ atau sebanyak 17 orang yang terdiri dari 12 orang kelas VII dan 5 orang peserta didik kelas VIII; serta peserta didik yang memiliki kemampuan bacaan Iqra dengan kriteria cukup baik yakni 35,7 \% atau sebanyak 10 orang Selanjutnya, mengenai Data Kehadiran Peserta dalam mengikuti kegiatan program mentoring, sebagai berikut yakni, peserta didik yang mengikuti kegiatan mentoring dengan sangat rutin yaitu $50 \%$ atau sebanyak 14 orang yang terdiri dari 13 orang peserta didik kelas VII dan 1 peserta orang didik kelas VIII, sedangkan peserta didik yang mengikuti kegiatan mentoring dengan rutin yaitu 21,4\% atau sebanyak 6 orang yang terdiri dari 5 orang peserta didik kelas VII dan 1 orang peserta didik kelas VIII, selanjutnya peserta didik yang mengikuti kegiatan program mentoring dengan cukup rutin yaitu $17,8 \%$ atau sebanyak 5 orang yang terdiri dari 3 orang peserta didik kelas VII dan 2 orang peserta didik kelas VIII, sedangkan peserta didik yang mengikuti kegiatan mentoring dengan tidak rutin yaitu $10,7 \%$ atau sebanyak tiga orang yang terdiri dari 2 orang peserta didik kelas VII dan 1 orang peserta didik kelas VIII

\section{Acknowledge}

Segala puji hanya milik Allaah Subhaanahu waTa'aala, berkat rahmat, hidayah serta karuniaNya, penulis dapat menyelesaikan skripsi ini dengan tepat waktu. Shalawat dan Salam, semoga senantiasa tercurah limpahkan kepada Nabi Muhammad Shallallaahu 'alayhi wasallam, keluarganya, para sahabat, dan pengikutnya hingga akhir zaman. Terselesaikannya skripsi ini, tentu tidak terlepas dari do'a, dukungan, dan bantuan dari berbagai pihak, sehingga pada kesempatan ini, dengan segenap ketulusan hati dan penuh rasa hormat, penulis mengucapkan Terimakasih banyak kepada:

1. Bapak Dr. Alhamuddin, M.M.Pd. selaku Pembimbing I dan Bapak Arif Hakim S.P., M.Pd selaku Pembimbing II yang telah bersedia meluangkan waktunya untuk membimbing dan memberikan arahan serta nasihat kepada penulis dalam menyelesaikan 
skripsi ini.

2. Ibu Dr. Hj. Erhamwilda, Dra., M.Pd, Bapak Dr. Alhammuddin, M.M.Pd, Bapak Eko Surbiantoro, Drs., M.Pd.I, dan Ibu Nurul Afrianti, S.P., M.Pd., M.Si, salaku dosen penguji pada saat sidang skripsi.

3. Bapak Prof. Dr. H. Edi Setiadi, SH., MH. Selaku Rektor Universitas Islam Bandung.

4. Bapak Enoh, Drs., M.Ag. selaku Dekan Fakultas Tarbiyah dan Keguruan Universitas Islam Bandung.

5. Bapak Dr. H. Aep Saepudin, Drs., M.Ag. selaku ketua Jurusan Program Studi Pendidikan Agama Islam.

6. Seluruh Dosen beserta Staff Tata Usaha Fakultas Tarbiyah Dan Keguruan Universitas Islam Bandung yang telah memberikan bimbingan dan memberikan ilmunya, sehingga penulis dapat menyelesaikan studi dan memperoleh gelar sarjana

\section{Daftar Pustaka}

[1] https://jabar.tribunnews.com/2020/02/08/sejumlah-kasus-bullying-sudah-warnai-catatanmasalah-anak-di-awal-2020-begini-kata-komisioner-kpai.

[2] Aisyah, S. (2019). PERANAN MENTOR BINA PRIBADI ISLAM DALAM MENINGKATKAN KECERDASAN SPIRITUAL SISWA KELAS VIII SMP IT BINA INSANI METRO TAHUN PELAJARAN 2018/2019. metrouniv.ac.id.

[3] Ali, M. (2020). Strategi Guru Akidah Akhlak dalam Menanggulangi Dekadensi Moral Peserta Didik di MTsN 2 Kota Blitar. 39.

[4] Al-Kattani, A. H., Muslim, \& Supraha, W. (2019). KONSEP ADAB PENUNTUT ILMU MENURUT IBN ADB AL-BARR DAN RELEVANSINYA DENGAN PENDIDIKAN NASIONAL. Tawazun Jurnal Pendidikan Islam, 281.

[5] Blegur, J. (2020). Soft Skils untuk Belajar (Disiplin, Percaya diri, Konsep diri akademik, Penetepan tujuan, Tanggung jawab, Komitmen, Kontrol diri). Surabaya: Scopindo Media Pustaka.

[6] El-Guyanie, G. (2008). Islam Madzhab Cinta: Dari Dogma Menuju Paradigma. Kutub Wacana.

[7] Elviana, P. S. (2017). Pembentukan Sikap Mandiri Dan Tanggung Jawab Melalui Penerapan Metode Sosiodrama dalam Pembelajaran Pendidikan Kewarganegaraan. Citizenship Jurnal Pancasila dan Kewarganegaraan, 139.

[8] Faturrohman, T. (2015, Januari). Peranan Akhlak Dalam Kehidupan Seorang Muslim. Retrieved from www.unisba.ac.id: https://www.unisba.ac.id/peranan-akhlak-dalamkehidupan-seorang-muslim/

[9] Fitriah, C. (2018). Pengelolaan Program Penguatan Pendidikan Karakter Religius di Sekolah Dasar Negeri Pancasila Lembang.

[10] Hanifah, N. (2014). Prosiding Seminar Pendidikan Dasar "Membedah Anatomi Kurikulum 2013 untuk Membangun Masa Depan Pendidikan yang Lebih Baik". Sumedang: UPT Sumedang Press.

[11] Jahja, Y. (2011). Psikologi Perkembangan. Jakarta: PRENADAMEDIA GROUP.

[12] Kompri. (2017). STANDARDISASI KOMPETENSI KEPALA SEKOLAH: Pendekatan Teori untuk Praktik Profesional. Jakarta: KENCANA.

[13] Kurniasih, I. (2010). Mendidik SQ Anak Menurut Nabi Muhammad Shallallahu 'alayhi wasallam. Yogyakarta: Pustaka Marwa.

[14] Martawijaya, M. A. (2016). MICROTEACHING "Model Pembelajaran Berbasis Kearifan Lokal". Makassar: CV. Masagena.

[15] Nurlaela, H. (2017). Analisis Program Pembinaan Keagamaan Bagi Anak Juara Penerima Beasiswa Ceria Rumah Zakat di Cimahi Utara.

[16] Prastiyo, F. (2019). Peningkatan Hasil Belajar Peserta Didik dengan Model Kooperatif Jigsaw pada Materi Pecahan di Kelas V SDN Sepanjang 2. Surakarta: Kekata Publisher.

[17] Prastiyo, F. (2019). PENINGKATAN HASIL BELAJAR PESERTA DIDIK DENGAN 
100 | Siti Alimah, et al.

MODEL KOOPERATIF Jigsaw PADA MATERI PECAHAN DI KELAS V SDN SEPANJANG 2. Surakarta: Kekata.

[18] Radja, A. S. (2018). Panduan Cepat dan Mudah Membaca Al-Qur'an. Yogyakarta: KAKTUS.

[19] Ramayulis, \& Nizar, S. (2010). Filsafat Pendidikan Islam: Telaah Sistem Pendidikan dan Pemikiran Para Tokohnya. Jakarta: Kalam Mulia.

[20] Ramli, M. (2015). Hakikat Pendidik dan Peserta Didik. Tarbiyah Islamiyah, 68.

[21] Setiawan, B. (2019). Pengaruh Kegiatan Mentoring Terhadap Hasil Belajar Pendidikan Agama Islam (PAI) Siswa Study di SMPIT Al-Izzah.

[22] Subagia, N. (2021). Pendidikan Karakter. Bandung: NILACAKRA.

[23] Suendra, I. W. (2019). Pengembanagan Model Pembelajaran Purana Berbasis Pemahaman Diri Untuk Meningkatkan Kecerdasan Spiritual. Bandung: NilaCakra.

[24] Sukatin, \& Saifillah Alfaruq, M. S. (2021). Pendidikan Karakter. Yogyakarta: Deepublish Publisher.

[25] Suprayitno, A. (2020). PENDIDIKAN KARAKTER Di Era Milenial. Yogyakarta: Deepublish.

[26] Surasman, O. (2002). Metode Insani (Kunci Praktis Membaca Al-Qur'an Baik dan Benar). Jakarta: Gema Insani.

[27] Veronica, V. (2019). EFEKTIVITAS MENTORING DALAM MENINGKATKAN PRESTASI BELAJAR SISWA PADA MATA PELAJARAN PENDIDIKAN AGAMA ISLAM (PAI) DI KELAS VII SMP IT KHOIRU UMMAH CURUP.

[28] Yaqin, A. (2020). PENDIDIKAN AKHLAK-MORAL BERBASIS KOGNITIF. Depok: PT RAJAGRAVONDO PERSADA.

[29] Zaenuri, A. (2021). PENDIDIKAN KARAKTER Melalui Konsep BOARDING SCHOOL (Evaluasi Program Boarding School SMP Islam Terpadu Abu Bakar Yogyakarta). Yogyakarta: Bintang Pustaka Madani.

[30] Zubaedi. (2011). DESAIN PENDIDIKAN KARAKTER: Konsepsi dan Aplikasinya dalam Lembaga Pendidikan. Jakarta: KENCANA. 